IJMS 16 (1), 97-113 (2009)

\title{
VARIATIONS IN PERFORMANCES IN CHINESE SMALL AND MEDIUM ENTERPRISES
}

\author{
MOHAMAD HANAPI MOHAMAD \\ College of Business \\ Universiti Utara Malaysia \\ CHING ING SUNG \\ Metal Roofing Industries Pte
}

\begin{abstract}
Malaysia, like many developing countries, is encouraging local businesses to take greater role in the management of its economy. While incentives and deregulation measures are offered, variations in performances still persist. Researchers have long been interested in explaining the variance in firm performance, as even those firms operating in the same industry and in the same business environment show differences in performance outcomes. Numerous paradigms in the literature have been employed to explain the variance in business performance, including the Classical Industry Organisation, the Revisionist school, the New Industrial Organisation school, the PIMS paradigm, the Austrian school, and the Resource-based school. This paper investigates the combined effects of managerial characteristics of owners/managers and business strategy on the firm performance of Chinese small and medium enterprises (SMEs) in Malaysia. Using multivariate relationship, the results of the study did not show any significant correlation between the managerial characteristics of the owners/managers and firm performance outcomes among the Chinese entrepreneurs. Nevertheless, a significant amount of variance in performance outcomes can be explained by firm strategy. Furthermore, several significant correlations were found between managerial characteristics and business strategy.
\end{abstract}

Keyword: Small medium enterprise; business performance; PIMS; resourcebased model; industrial organizational; managerial characteristic and business strategy.

\begin{abstract}
ABSTRAK
Malaysia seperti kebanyakan negara membangun menggalakkan penyertaan pengusaha dan korporat tempatan dalam pengurusan ekonomi negara.
\end{abstract}


Meskipun pelbagai insentif, galakan serta langkah-langkah deregulasi telah diperkenalkan kepada pengusaha dan peniaga ini, pencapaian keseluruhan masih terdapat variasi. Sudah beberapa ketika penyelidik-penyelidik sangat berminat untuk mengkaji dan memberi jawapan mengapa berlaku variasi di dalam pencapaian organisasi dan korporat, meskipun entiti ini di dalam industri serta beroperasi di dalam persekitaran yang sama. Pelbagai model telah dicadangkan bagi menerangkan mengapa berlaku variasi di dalam pencapaian organisasi, termasuk mereka yang mengutarakan model Classical Industry Organization, New Industrial Organization School, PIMS Paradigm, Austrian Economics School dan Resource-based Model. Kajian ini membuat penyiasatan mengenai kesan bersama ciri-ciri pengurusan pengusaha dan pengurus syarikat dan strategi perniagaan ke atas pencapaian korporat bagi syarikat-syarikat saiz sederhana masyarakat China di Malaysia. Dengan menggunakan kaedah hubungan multivariate, hasil kajian ini tidak menunjukkan korelasi yang signifikan antara hubungan ciri-ciri pengurusan pengusaha/pengurus dengan pencapaian organisasi. Walau bagaimanapun wujudnya variasi di dalam pencapaian yang signifikan adalah disebabkan syarikat mengguna pelbagai strategi operasi di samping terdapat korelasi yang signifikan antara ciri-ciri pengurusan dan strategi perniagaan.

\section{INTRODUCTION}

SMEs account for $99.2 \%$ of businesses and $65.1 \%$ of the total workforce in Malaysia (Leong, 2006; The Star Business, August 8, 2006). However, they contribute only $47.3 \%$ of the gross domestic product (GDP), which is lower than that of more developed countries like South Korea (50\%), Japan (55.3\%), Germany (57\%) and China (60\%), according to a report from the National Economic Action Council of Malaysia (Leong, 2006). Moreover, each year about 37,000 new businesses have been started for the past five years (SSM, 2007), where the failure rate is about $60 \%$ within the first five years (Omar, 2006).

Factors relating to business failure are many, but those relating to business management and the business experience of top managers, and turbulent environmental factors account for most business failures. According to Dun and Bradstreet ${ }^{1}$ statistics in the SME literature, $88.7 \%$ of all business failures are due to management mistakes; the major causes include managerial incompetence $(46 \%)$, unbalanced experience or lack of managerial experience $(30 \%)$, and lack of experience in the line of goods or services (11\%). However, the development of a business (strategic) plan and the acquisition of accurate financial information 
about the business in a timely manner, among others, should assist in the improvement of the chances of success (Holland, 1998).

The Chinese SMEs are an important component of the Malaysian economy with the statistics showing that Chinese ownership of share capital of limited companies (of which $99.2 \%$ are SMEs) stands at $40.9 \%$ compared to $18.7 \%$ for the Bumiputra (the indigenous group), with the balance in the hands of foreigners and nominee companies (EPU, 2005). Despite its economic importance, research on Chinese SMEs in Malaysia has been scant; no study, conducted to investigate the impact of managerial characteristics, business strategy, and business environment in combination, has been uncovered to-date in the literature. These factors are reflected in the business performance of a firm, and here, a research model is proposed to study the relationships. As shown in Figure 1, this model identifies three constructs that influence the business performance.

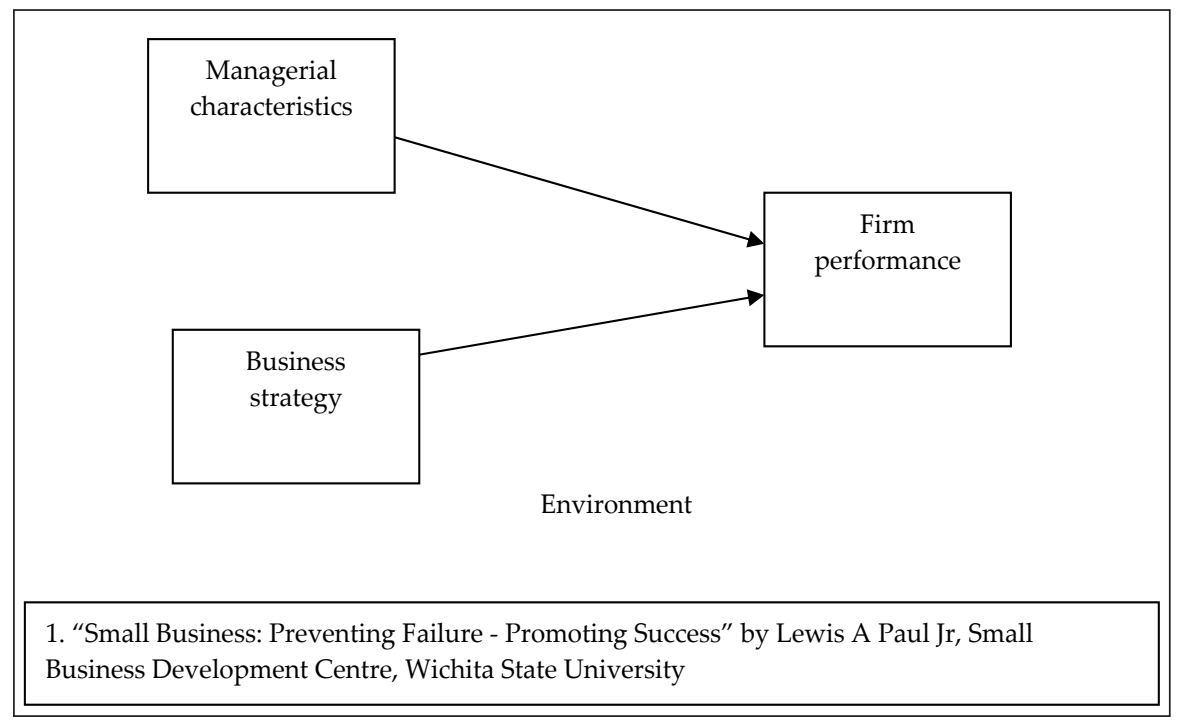

Figure 1: Proposed research model

This research model, which is discussed in detail in Section 3, is utilised in this study to address the primary research question: Is there an association between the specified managerial characteristics of owners/ managers, the business strategy and the business performance of Chinese SMEs? Specifically, four research questions were asked: 
1. Are selected managerial characteristics of age, education level, and tenure of owners/managers associated with the business strategy choice of Chinese SMEs?

2. Are selected managerial characteristics of age, education level, and tenure of owners/managers associated with business performance outcomes of Chinese SMEs?

3. Are choices of business strategies associated with business performance outcomes of Chinese SMEs?

4. Are business environmental factors moderating the relationship between business strategy and business performance outcomes of Chinese SMEs?

\section{LITERATURE REVIEW}

Researchers have been long interested in explaining the variance in firm performance, as even those firms operating in the same industry and in the same business environment show differences in performance outcomes. Antecedents and correlates of firm performance have attracted a lot of attention from both researchers and practitioners. Numerous paradigms in the literature have been employed to explain the variance in business performance, including the Classical Industry Organisation school, the Revisionist school, the New Industrial Organisation school, the PIMS paradigm, the Austrian school, and the Resource-based view of the firm. Traditionally, researchers had focused on the role of industry factors in explaining variance in firm performance; they tended to base their research on the structure-conduct-performance (S-C-P) paradigm (Bain, 1951; Bain, 1956) which argued that structure influences conduct (strategy) and thereafter impacts on performance. However, empirical support for this paradigm is limited. More recent work of Wernerfelt and Montgomery (1988) found that industry factors explain only about $15-20 \%$ of variance in performance. Strategy has been found to be as important as, if not more important than, the structure as a determinant of firm performance; this has caused a shift of focus of research on performance to firms within industries.

Using the SWOT analysis framework, researchers argued that firms are more likely to achieve competitive advantage and superior performance through effective business strategies that exploit strengths and opportunities while neutralising threats and weaknesses, as noted by Hofer and Schendel (1978), and Barney (1991) (Halawi, McCarthy, \& Aronson, 2006). Michael Porter (Porter, 1980), on the other hand, proposed 
his generic strategies for firms to cope successfully with competitive forces and achieve superior returns, and maintain a position defensible in the long run (Onsman, 2004). Demsetz (1974) of the efficiency/revisionist school argued that it is efficiency that really matters as efficient firms possess superior characteristics which in turn increase their market share and profit. More recently, this market-share-profitability stream of research has been criticised by a number of researchers who argued that it is the firm-specific unobservable third factors related to both market share and profitability that are important (Boulding \& Staelin, 1990). Support for these firm-specific factors come from the resourcebased theory of firms which argued that firms can earn higher profit and higher market share if they have better resources and make better use of these resources. Nevertheless, none of these paradigms provide a satisfactory explanation for the variance in firm performance.

A review of literature revealed that there are alternative views on the explanation of variance in firm performance. More recently, strategic leadership literature suggested that the CEOs and governance boards influence strategic choices and have aneffect on the performance outcomes (Roth, 1995). The said literature emphasised the characteristics of top managers who have responsibility in positively influencing performance outcomes. The literature got a significant boost when Hambrick and Mason (1984) introduced the "Upper Echelons" perspective founded on the premise that decisions are based on behavioural rather than economic factors. Top managers' personal beliefs, values, and experiences are the foundation for the interpretation of the environment and these influence their actions within their firms. Another stream of research had focused on the fit between the strategy and the environment. Gupta and Govindarajan (1984), for instance, studied the relationship of fit with performance and they found that business units are more successful when the managers' experiences and personalities are aligned with the requirements of the chosen strategy. Rajagopalan and Datta (1996), on the other hand, suggested that the alignment of CEO characteristics and industry effects is associated with firm superior performance when firm strategy is controlled. Several constructs however, have emerged as the foci of investigation; these include managerial characteristics, business strategy, and the environmental factors.

The existing literature revealed that these few constructs have been examined either alone or in some combination in a relationship to the firm's performance, and significant relationships between one and more of these constructs had also been reported. However, there are very few 
empirical studies which examined all these constructs simultaneously in the SME sector. The previous models could have been underspecified, especially when multivariate relationships exist between one or more variables of these constructs. This study examined managerial characteristics of the owners/managers of Chinese SMEs in Sarawak and the business strategy of the firms in relation to firm performance as moderated by business environmental factors. This study revealed that several of these variables are correlated. Moreover, the combination of these variables explain the variance in business performance to a greater extent than when they are examined in isolation or to a lesser combination. The results of this exploratory study are useful in contributing to the understanding of differences in business performance as a whole in Chinese SMEs in Sarawak.

\section{METHODOLOGY}

The population of the study was limited to the member firms of the Association of Chinese Chamber of Commerce and Industry Sarawak. The specific variables selected were limited to those that have been identified in prior research in literature. The definition of Chinese SMEs which was used in defining the population for this study was given as follows: a Chinese SME is a private limited company with the majority of shares owned by Chinese and with an annual turnover below RM25 million or with fewer than 150 full-time employees in the manufacturing and related sectors, and with an annual turnover below RM5 million or with fewer than 50 full-time employees for the services sector.

The analysis framework for the study was based on the premise that an integrated model of Porter's generic strategy as well as Hambrick and Mason's (1984) upper echelons perspective is a useful tool for objectively examining the managerial characteristics and business strategy of a business. Previous researchers had also found it useful for examining the overall financial performance in terms of return of equity (ROI) using the age as a proxy for managerial characteristics and the Miles and Snow (1978) typology on large firms in a single industry. However, no previous research studies had been found in the literature that evaluate the financial and non-financial performance outcomes of SMEs in Sarawak in terms of multiple variables of managerial characteristics and Porter's (1980) generic strategy as moderated by environmental factors.

This study was particularly motivated by a desire to address three key gaps in prior literature on the impact of managerial characteristics of 
owners/managers and business strategy on the business performance of Chinese SMEs in Sarawak, as follows:

1. the relationship between the managerial characteristics of owners/managers of Chinese SMEs and business performance,

2. the relationship between the business strategy of Chinese SMEs and business performance, and

3. the correlations between the managerial characteristics of owners/managers of Chinese SMEs, business strategy, and business performance in the context of a changing business environment.

\section{FINDINGS AND CONCLUSION}

This section provides a summary description of the survey results and the results of the test of hypotheses from qualitative and quantitative data collected from Chinese SMEs in Sarawak.

Several important findings had emerged from this study, some were expected and some surprising, but interesting. An examination of the correlations between some of the variables provided significant findings on the relationships among the various constructs of the sample.

This study sought to fill the gaps in our understanding on the impact of managerial characteristics of Chinese SMEs' owners/managers and business strategy upon business performance as moderated by the business environment. Pearson product-moment correlations, one-way ANOVA, and stepwise multiple regression were used to explore evidence from a small sample relating to an SME environment in Sarawak, as well as the business strategy and demographic characteristics of owners/ managers.

Results of the one-way ANOVA showed that younger owners/ managers are associated with the focus strategy (H2, H3, H4) instead of differentiation strategy as suggested in the literature, while older owners/ managers are associated with the low-cost strategy, consistent with the work of Thomas, Litschert, and Ramaswamy (1991). In addition, higher educated owners/managers in this sample are associated with the focus strategy (H7) in contrast to the findings of Thomas et al. (1991). On the other hand, longer tenure owners/managers are associated with the lowcost strategy (H9), which is consistent with the findings of Gupta (1984) 
and Thomas et al. (1991). In terms of strategy type and performance, firms pursuing the differentiation strategy are not associated with a higher performance level compared to those pursuing the low-cost strategy. In fact, for this sample, there is significant difference between the performance levels of firms pursuing differentiation and low-cost strategies. Furthermore, firms which pursue the focus strategy achieve a significant higher level of performance than those adopting the other strategy types.

The results of Pearson product-moment correlations did not support the hypothesis that the age of owners/managers is negatively related to firm performance (H1). The hypotheses that higher level of education of owners/managers was positively associated with higher level of firm performance $(\mathrm{H} 8)$, and that longer tenure owners/managers were positively associated with firms pursuing low-cost strategy (H10), which was only weakly supported.

Results of the stepwise multiple regression analysis demonstrated that both environmental uncertainty and changes in the environment moderate the relationships between the managerial characteristics of owners/managers, business strategy, and the business performance.

\section{Managerial Characteristics and Business Strategy}

Managerial characteristics were defined in this study in terms of age, highest educational level, and tenure of the owners/managers of Chinese SMEs whilst the business strategy was defined in terms of Porter's (1980) generic strategies of low cost, differentiation, and focus (niche). The findings relating managerial characteristics and business strategy are summarised in Table 1.

Table 4.1: Managerial Characteristics and Business Strategy

\begin{tabular}{lcll}
\hline Managerial Characteristics & $\begin{array}{c}\text { Expected } \\
\text { Sign }\end{array}$ & Business Strategy & Research Findings \\
\hline Younger age & $(+)$ & Differentiation & Not supported \\
Older age & $(+)$ & Low-cost & Supported \\
Mid-range age & $(+)$ & Focus & Not supported \\
Higher education level & $(+)$ & Differentiation & Not supported \\
Longer tenure & $(+)$ & Low-cost & Supported \\
\hline
\end{tabular}

In this sample, there existed significant correlations between the age of the owners/managers and the strategy types of their firms. The correlations 
between the age of owners/managers, and the differentiation strategy and focus strategy adopted by their firms, were negative and substantial. That is, the younger the age of the owners/managers, the more likely that their firms will pursue focus and differentiation strategies. On the other hand, the correlation between the age of owners/managers and the low-cost strategy adopted by their firms was positive and significant. This means that the older the age of owners/managers, their firms will more likely pursue the low-cost strategy. These findings are consistent with the literature that managerial characteristics (where age is one of them) would be correlated with all strategy types, where older managers being more inclined to adopt the low-cost strategy -(Thomas et al., 1991). This is also consistent with previous studies which indicated an inverse relationship between the risk taking propensity of managers and their age (Hambrick \& Mason, 1984).

There is a theoretical justification for using age of managers as a surrogate for managerial characteristics, and it is assumed that other managerial characteristics like education levels and tenure of managers are related with their age. The younger owners/managers are more likely to be higher educated, while the older ones tend to have a longer tenure with their firms (Domicone, 1997). The statistically significant correlations between the age of owners/managers and strategy types of firms for this sample are in the direction of hypothesised relationships. However, the finding that firms with younger owners/managers tend to pursue focus strategy is interesting. This could be linked to their higher education level and inclination to scan the business environment, and to use analytical tools to focus on their niche market instead of the wider market.

For this sample, there existed a positive correlation between the education level of owners/managers and the strategy types pursued by their firms. However, only the correlation between the education level of owners/managers and the focus strategy pursued by their firms was statistically significant. The education level of owners/managers of firms pursuing the focus strategy was significantly higher than those owners/ managers of firms that pursue the low-cost strategy and differentiation strategy. On the other hand, the education levels of owners/managers of firms that pursue the low cost strategy and those that pursue the differentiation strategy were not significantly different. This observation was inconsistent with the findings of previous studies showing that top managers of firms pursuing the differentiation strategy possess a higher level of education than firms pursuing the low-cost strategy (Thomas et al., 1991). This could be explained by the focus strategy used by younger 
and more highly educated owners/managers, which according to the literature is the better strategy for SMEs due to their limited resources. This pursuing of focus strategy conforms to the objective of many owners/managers that are driven more by survival and independence than by growth and by business development (Wheelen \& Hunger, 1999; Beaver \& Prince, 2004).

In this sample, there existed also significant correlations between the tenure of the owners/managers and the strategy types of their firms. The correlations between the tenure of owners/managers and the focus strategy adopted by their firms were negative and substantial. That is, the shorter the tenure of the owners/managers, the more likely that their firms will pursue the differentiation and focus strategies. On the other hand, the correlation between the tenure of owners/managers and the low-cost strategy adopted by their firms was positive and substantial. This means that the longer the tenure of the owners/managers, the more likely their firms will pursue a low-cost strategy. These findings are consistent with the literature that tenure would be correlated with all strategy types, with longer tenured managers being more inclined to adopt a low-cost strategy while the shorter tenured managers would be more inclined to adopt a differentiation strategy (Thomas et al., 1991). This is in consistent with previous studies that indicated that an inverse relationship between the risk taking propensity of managers and their tenure, and that to achieve the internal efficiency and control necessary to achieve cost leadership position would require managers to be long enough in their position so as to be familiar with their business and environment (Gupta, 1984). The statistically significant correlations between the tenure of owners/managers and strategy types of firms for this sample were in the direction of hypothesised relationships. However, the firms with shorter tenure owners/managers tended to pursue focus strategy is interesting. This could be linked to their younger age and higher education level, and more inclination to scan the business environment and focus on their niche market instead of the wider market.

Business Strategy and Business Performance

Table 2: Business Strategy and Business Performance

\begin{tabular}{ll}
\hline \multicolumn{1}{c}{ Business Performance } & Research Findings \\
\hline Differentiation strategy outperforms low-cost strategy & Not supported \\
$\begin{array}{l}\text { Focus strategy performs between that of low-cost and } \\
\text { differentiation strategies }\end{array}$ & Not supported \\
\hline
\end{tabular}


The findings relating to the hypotheses concerning the relationship between business strategy and business performance are shown in Table 2. Correlations were observed between business performance and several strategy types. Focus strategy reported an average growth in ROS significantly higher than the other two strategies. Similarly, firms pursuing focus strategy reported an average growth in ROI significantly higher than that of firms pursuing a low-cost strategy. However, there was no significant difference in average growth in ROS and ROI for firms pursuing differentiation and low-cost strategy. This is not in consistent with the prior studies that firms pursuing differentiation strategy reported higher performance than other strategy types (Reklitis \& Trivellas, 2002). For this sample, the firms pursuing the low-cost strategy generated the lowest financial outcomes in consistent with prior studies. However, SMEs with their small sizes and limited resources trying to compete in the wider market with the big firms might be difficult for them. Focus strategy is the better option for them to concentrate their efforts in a certain niche market. Finally, in terms of financial performance outcomes, there was a significant correlation between the average growth in sales for firms pursuing differentiation strategy. Firms pursuing differentiation strategy reported an average growth in sales significantly higher than those firms pursuing a focus strategy, but not significantly higher than those pursuing the low-cost strategy. This is in consistent with previous studies that competing on low cost-strategy and differentiation strategy in the bigger markets will generate higher sales than the restricted niche market.

In terms of non-financial performance outcomes, significant correlation was found between the non-financial achievements in various areas, NFA, and the differentiation strategy and focus strategy. Similarly, significant correlation was found between the non-financial satisfaction in added value to various vested parties, NFS, and the differentiation strategy and focus strategy. However, there was no significant correlation between these non-financial performance outcomes and the low-cost strategy. This is consistent with the previous study that low-cost strategy yields the lowest returns, and this current study validated the earlier findings. However, the focus strategy yielded the highest non-financial returns for this sample in contrast with the previous studies that differentiation strategy is associated with higher performance outcomes than other strategy types. This could be explained by the focus strategy practised by SMEs which according to the literature is the better strategy for SMEs due to their limited resources, and they are driven more survival and independence than by growth and business development, argued (Wheelen \& Hunger, 1999; Beaver \& Prince, 2004). 


\section{Managerial Characteristics and Business Performance}

Table 3: Managerial Characteristics and Business Performance

\begin{tabular}{lcl}
\hline \multicolumn{1}{c}{ Managerial Characteristics } & Expected Sign & \multicolumn{1}{c}{ Research Findings } \\
\hline Age & $(-)$ & Not supported \\
Education level & $(+)$ & Weakly supported \\
Tenure & $(-)$ & Weakly supported \\
\hline
\end{tabular}

The relationship between the age of owners/managers and performance outcomes was mixed (some positively and some negatively correlated), as shown in Table 3 above. The only correlation that was significant is between average growth in sales and the age, but this positive correlation is inconsistent with the results of prior studies. Studies by Child (1974) and Norburn and Birley (1988) indicated that younger CEOs show superior performance outcomes. The results of this study revealed that no significant correlation between the age of owners/managers and the performance outcomes. These results however, are consistent with the study by Karami, Analoui, andKakabadse (2006) and Domicone (1997). It was likely that due to the restricted range of age of owners/managers thus no significant relationships emerged from this study. A large sample size may result in significant correlations.

On the other hand, the relationship between the education levels of owners/managers and performance outcomes was positive except for the average growth in sales. However, the only significant positive correlations that were significant are between the two non-financial performance outcomes and the education levels. These positive correlations are consistent with the results of prior studies, for instance, Norburn and Birley (1988) found a link between the level of education and firm performance. This can be explained by the vast technological knowledge of the higher educated owners/managers resulting in higher non-financial performance outcomes beneficial to their firms in the longer term, instead of just aiming for short term financial performance. The financial performance of this sample of SMEs is not significantly related to the educational level of their owners/managers. This finding is similar to the results of previous studies in the field (Karami et al., 2006).

The relationship between the tenure of owners/managers and performance outcomes was mixed (some positively and some negatively correlated). The only correlation that was significant is between average growth in sales and the tenure, but this positive correlation is consistent with the results of prior studies. This can be explained by 
the vast managerial work experience and knowledge of the market of the longer tenure owners/managers resulting in higher growth in sales. This result is similar to the results of previous studies in the field (Karami et al., 2006). However, the overall results of this study revealed that no significant correlation between the tenure of owners/managers and performance outcomes, except for sales. A bigger sample size may produce more significant results on the correlations between the tenure and performance outcomes.

\section{Managerial Characteristics, Business Strategy, Business Environment and Performance}

An important finding of this study was that the firm performance of SMEs can be explained better by considering the managerial characteristics (as measured by age, education levels, and tenure of owners/managers), business strategy, (using Porter's generic strategy), and business environment (as measured by the degree of predictability of the environment and perceived changes in the business environment). These three variables in combination could explain the variance in performance to a larger extent than a more limited combination of variables. This finding is in consistent with the original premise of the study that managerial characteristics, business strategy, and business environment together contributed to the performance.

Notwithstanding that managerial characteristics alone did not produce a statistically significant explanation of explained variance in performance outcomes, a strong multivariate relationship emerged between managerial characteristics, firm strategy, and environment that can explain the variance in some of the performance measured.

Table 4: The final regression equation and regression Table for Average growth in ROS for 2002-2004

\begin{tabular}{|c|c|c|c|c|c|c|c|}
\hline Step & $\begin{array}{l}\text { Variables } \\
\text { Entered }\end{array}$ & B & $\mathrm{R}$ & $\mathrm{R}^{2}$ & $\begin{array}{l}\text { Change } \\
\text { In } R^{2}\end{array}$ & $\mathrm{~F}$ & $\begin{array}{l}\mathrm{F} \\
\text { Change }\end{array}$ \\
\hline 1 & $\begin{array}{l}\text { Constant } \\
\text { Different. } \\
\text { Focus }\end{array}$ & $\begin{array}{r}0.059 \\
-0.068 \\
0.076\end{array}$ & 0.415 & 0.172 & & $\underset{* *}{9.685}$ & \\
\hline 2 & $\begin{array}{l}\text { Constant } \\
\text { Different. } \\
\text { Focus } \\
\text { Uncertainty } \\
\text { In envir. }\end{array}$ & $\begin{array}{r}0.172 \\
-0.067 \\
0.093 \\
-0.015\end{array}$ & 0.485 & 0.236 & 0.063 & $\begin{array}{c}9.447 \\
* *\end{array}$ & $\begin{array}{c}7.596 \\
*\end{array}$ \\
\hline
\end{tabular}


The final regression equation can be stated:

Average growth in ROS $=0.172+(-0.067 \times$ differentiation strategy $)+$ $(0.093 \times$ focus strategy $)+(-0.015 \times$ changes in environment $)$

For average growth in sales, the combination of the age of owners/ managers and differentiation strategy of the firms explained a significant amount of variance in this performance measure. The regression equation which took into account the age and differentiation strategy explained $18.5 \%$ of variance in average growth in sales $(\mathrm{F}(2,93)=10.586$, $\mathrm{p}<0.001$ ). When the environment variables (uncertainty in environment and changes in environment) were added to the equation, $27.8 \%$ of the variance was explained $(\mathrm{F}(4,91)=8.762, \mathrm{p}<0.001)$.

For average growth in ROI, the combination of the low-cost strategy and focus strategy of the firms explained a significant amount of variance in this performance measure. The regression equation which took into account the low-cost strategy and focus strategy explained $11.8 \%$ of variance in average growth in ROI $(F(2,92)=6.134, \mathrm{p}<0.003)$. When the environment variable (changes in environment) was added to the equation, $23.5 \%$ of the variance was explained $(F(3,91)=9.318, p<0.001)$.

For average growth in ROS, the combination of differentiation strategy and focus strategy of the firms explained a significant amount of variance in this performance measure as shown in Table 4 . The regression equation which took into account the differentiation strategy and focus strategy explained $17.2 \%$ of variance in average growth in $\operatorname{ROS}(F(2,93)=9.685$, $\mathrm{p}<0.001)$. When the environment variable (uncertainty in environment) was added to the equation, $23.6 \%$ of the variance was explained $(F(3,92)$ $=9.447, \mathrm{p}<0.001$ ).

For non-financial achievements in various areas, NFA, the combination of the age and education level of owners/managers and focus strategy of the firms explained a significant amount of variance in this performance measure. The regression equation which took into account the age and education level of the owners/managers and the focus strategy explained $39.8 \%$ of variance in non-financial achievements in various areas, NFA, $(\mathrm{F}(3,97)=21.389, \mathrm{p}<0.001)$. When the environment variable (uncertainty in environment) was added to the equation, $48.6 \%$ of the variance was explained $(\mathrm{F}(4,96)=22.702, \mathrm{p}<0.001)$.

For non-financial satisfaction in value-added outcomes to various vested parties, NFS, the combination of the age and tenure of owners/ 
managers and focus strategy of the firms explained a significant amount of variance in this performance measure. The regression equation which took into account the age and tenure of owners/managers and the focus strategy explained $33.1 \%$ of variance in non-financial achievements in various areas, NFS, $(\mathrm{F}(3,97)=15.975, \mathrm{p}<0.001)$. For this performance measure, the environment variables (uncertainty in environment or changes in environment) were not added to the equation since they are not significant in explaining the variance.

On the whole, the results of stepwise multiple regression show that the relationship business strategy and performance of Chinese SMEs is moderated by the environment factors, similar to previous findings, for instance, the work of Hashim, Wafa, and Sulaiman (2001) on Malaysian SMEs.

\section{REFERENCES}

ACCCIS. (2005). Brief history of Associated Chinese Chamber of Commerce and Industries of Sarawak. Kuching.

Bain, J. (1951). Relation of profit rate to industry concentration: American manufacturing 1936-1940. Quarterly Journal of Economics, 65, 293324.

Bain, J. (1956). Barriers to new competition. Cambridge: Harvard University Press.

Barney, J. (1991). Firm resources and sustained competitive advantage. Journal of Management, 17(1), 99-120.

Beaver, G., \& Prince, C. (2004). Management, strategy and policy in the UK small business sector: A critical review. Journal of Small Business and Enterprise Development, 11(1), 34-49.

Boulding, W., \& Staelin, R. (1990). Environment, market share, and market power. Management Science, 36, (October), 1160-77.

Child, J. (1974). Managerial and organisational factors associated with company performance. Journal of Management Studies, 11, 13-27.

Demsetz, H. (1974). Two systems of belief about monopoly. In H. Goldschmidt (Ed.), Industrial concentration: The new learning. (pp. 21). Boston: Little Brown and Company.

Domicone, H. A. (1997). Management characteristics, business strategy and technology policy: An empirical investigation. Unpublished Ph.D Dissertation, University of Cincinnati, Cincinnati.

EPU. (2005). Key economic indicators. Economic Planning Unit Malaysia. 
Gupta, A. K. (1984). Contingency linkages between strategy and general manager characteristics: A conceptual examination. Academy of management Review, 4(3), 34-47.

Gupta, A., \& Govindarajan, V. (1984). Business unit strategy, managerial characteristics, and business unit effectiveness at strategy implementation. Academy of Management Journal, 27 (January), 2541.

Halawi, L. A., McCarthy, R. V., \& Aronson, J. E. (2006). Knowledge management and the competitive strategy of firm. The Learning Organisation, 13(4), 384-97.

Hambrick, D. C., \& Mason, P. A. (1984). Upper echelons: The organisation as a reflection of its top managers. Academy of Management Review, 9, 193-206.

Hashim, M. K., Wafa, S. A., \& Sulaiman, M. (2001). Testing environment as the moderator between business strategy-performance relationship: A Study of Malaysian SMEs. School of Management. Sintok: Universiti Utara Malaysia.

Hofer, C., \& Schendel, D. (1978). Strategy formulation: Analytical concepts. St. Paul, MN: West Publishing Company.

Holland, R. (1998). Planning against a business failure. Unpublished PhD Thesis, The University of Tennessee, Tennessee.

Karami, A., Analoui, F., \& Kakabadse, N. K. (2006). The CEOs' characteristics and their strategy development in the UK SME sector: An empirical study. Journal of Management Development, 25(4), 316-24.

Leong, N. (2006). SMEs contributing 47\% to GDP. Retrieved February 8, 2007, from http//www. neac.gov.my

Miles, R E., \& Snow, C. C. (1978). Organisational strategy, structure, and process. New York: Mc Graw Hill.

Norburn, D., \& Birley, S. (1988). The top management team and corporate performance. Strategic Management Journal, 9, 225-36.

Omar, T. (2006). PUNB's soft loan scheme sustained 60\% failure rate. Retrieved February 8, 2007, from http//www.theedgedaily.com

Onsman, H. (2004). Management powertools: A guide to 20 of the most powerful management tools and techniques ever invented. Australia Pty Ltd. North Ryde: NSW, McGraw-Hill.

Porter, M. E. (1980). Competitive Strategy. New York: Free Press.

Rajagopalan, N., \& Datta, D. K. (1996). CEO characteristics: Does industry matter? Academy of Management Journal, 39(1), 197-215.

Reklitis, P., \& Trivellas, P. (2002). Performance implications of aligning generic strategies with business performance. International Journal of Management and Decision Making, 3(3 and 4), 319. 
Roth, K. (1995). Managing international interdependence: CEO characteristics on resource-based framework. Academy of Management Journal, 38(1), 2002-31.

SSM (2007). Companies commission of Malaysia. Statistics of companies. Retrieved January 20, 2007, from http//www.ssm.com.my

Thomas, A. S., Litschert, R. J., \& Ramaswamy, K. (1991). The performance impact of strategy-manager co-alignment: An empirical examination. Strategic Management Journal, 12, 509-22.

Wernerfelt, B., \& Montgomery, C. A. (1988). Tobin's q and the importance of focus in firm performance. American Economic Review, 78(March), 246-50.

Wheelen, T. L., \& Hunger, J. D. (1999). Strategic management and business policy. New York: Addison-Wesley. 